HStud 25 (2011)2, 227-233 DOI: 10.1556/HStud.25.2011.2.5

\title{
SELF-DETERMINATION AND STABILITY IN EUROPE: AN UNEASY BALANCE
}

\author{
LÁSZLÓ BORHI \\ Indiana University \\ Bloomington, IN, USA
}

\begin{abstract}
This paper traces the international history of Eastern Europe in the 20th century within the analytical framework of the national self-determination/independence paradigm. It argues that in 1918 the allied powers dissolved the Austro-Hungarian Monarchy in the hope that the newly established nation states would strengthen European stability and would balance Russian and German power. The Munich agreement was not a mistake but a conscious effort to reorganize the continent on a more stable basis after it turned out that the international system created for middle Europe in Paris was not working. Thereafter Great Britain strove to achieve continental balance by surrendering the region to German, later to Soviet hegemony. This would also be the policy of the United States until 1948 when the Truman administration decided that the restoration of national independence in Eastern Europe would create a safer Europe. After the failure of the 1956 Hungarian Revolution the U.S. returned to the position that continental stability took precedence over the independence of the Soviet satellites, a view shared by the major NATO allies. This remained the Western position through 1989. The restoration of national independence and continental reunification originated in Eastern Europe, which for the first time since 1918 was a policy maker in the international arena.
\end{abstract}

Keywords: national self-determination, continental stability, security, World War I, Paris treaties, the Munich Conference, World War II, 1956 Hungarian Revolution, the Prague Spring, regime change, continental reunification

\section{National Self Determination vs. Continental Security and Stability}

The Habsburg Monarchy, which had dominated the Central European scene for half a millennium went to war in 1914 to preserve its territorial integrity. Edward Grey noted ominously: "The lamps are out all over Europe. We shall not see them lit again in our time." The quest for more security ended in self-destruction. When Austria-Hungary's effort to sign a separate peace failed, it seemed to outlive its usefulness as a balance between Russia and Germany. When the Entente powers decided to dissolve the Monarchy into independent national entities, they were primarily motivated by strategic calculations. Some in the British Foreign Office 
were unconvinced that anything better would come from dissolving the Monarchy but such views were brushed aside. In fact it looked as though that, the new states would constitute an effective buffer zone between Germany and Soviet Russia. National independence and stability were seen as mutually reinforcing principles. Containing Bolshevism in Russia was a key factor in redrawing the boundaries of Central Europe. Strategically important railroads, which would facilitate mobilization against Russia, were given to "friendly" successor states even at the price of violating ethnic self-determination. Territory was granted in accordance with the security services each state was expected to provide for Britain and France, the chief beneficiaries being Poland, Romania and Czechoslovakia. Territorial awards were thus meant to increase stability in Eastern Europe. As it turned out, the unintended, although not quite unforeseen consequence was the opposite: revisionist sentiment in Germany, Soviet Russia, Hungary and even Bulgaria led to the disruption of Middle Europe. Instead of more security the allies ended up with less.

The high hopes attached to national independence as a stabilizing factor in Central Europe quickly faded as the former entente powers were unable to stabilize the economies and politics of the newly created states. Only a few years after dismembering the Monarchy the Foreign Office and even the Quai D'Orsay thought of resuscitating the old. In fact the restoration of the economic unity and thereby the political integrity of Austria-Hungary was an elusive goal both London and Paris would seek. But Humpty Dumpty could not be put together again: Central Europe's "pauper states" as the British called them were hopelessly divided between revisionist and status quo powers. Neither the British nor the French were willing to provide workable security guarantees for their clients. A case in point was Romania which sought, but never received French guarantee against the Soviets for Bessarabia. Neither was France willing to guarantee the Little Entente against the Hungarians. Economic recovery was obstructed by nationalist isolation, some of the new states, including Hungary and Austria seemed unviable. At the same time the victors competed for influence in what they saw as a zero sum game. Paris and Rome constructed their respective blocs while London was wary of the undue influence France enjoyed in the center of Europe, prompting it to give up its anti-Hungarian stance and support Budapest against the bloc sponsored by the French.

But as recent scholarship has shown, Britain wrote off Central Europe by the end of the 1920s. Even though Paris offered paper guarantees to its allies in the mid 1930s they were not intended to be kept. London was unable to find a pillar on which to base its influence in Eastern Europe. Even Czechoslovakia was a disappointment, because it obstructed regional reconciliation. "All these states", wrote permanent undersecretary of foreign affairs Robert Vansittart, "like France are obsessed by anxiety to keep what they got out of the war and to preserve the status 
quo against those neighbors whom the war despoiled... their peppery weakness and local brawls have been a disappointment (they are) unreliable allies in the pursuit of this haunting and evasive "security"'. The newly created states in Central Europe rapidly outlived their usefulness for Western security. Both London and Paris hoped that Germany could be satisfied in middle Europe. Appeasement cannot be explained with unsatisfactory military preparedness or the desire to avoid war at all costs only. Recent scholarship indicates that disenchantment with the international system created in Paris played a role; it was hoped that new boundaries in Central Europe and German mastery there will bring about a more just peace and hence a more stable continent. German hegemony over the smaller states was not seen as threat but rather as an enhancement of Western security. In 1938 Austria was annexed by the Reich. Thereafter the western powers bullied Czechoslovakia into accepting Hitler's demands and arbitrated its partition. Chamberlain returned from Munich genuinely convinced that it was possible to remodel Europe in a peaceful and just manner. French officials stated that the British and the French almost went to war to boost up a state that was not viable. In 1939 Czechoslovakia was dismembered, neither Britain nor France honored their commitment to guarantee Czechoslovakia's borders on the grounds that the state had ceased to exist before Germany invaded it. British objectives would not be impeded by German control of Central Europe. When Hitler destroyed Czechoslovakia precisely two decades after it was helped to life by British liberals Chamberlain explained British inaction: "The object that we have in mind is of too great a significance to the happiness of mankind for us to lightly give it up."

In August and September 1939 Berlin and Moscow divided the north eastern tier, Poland was destroyed as an independent state. It seemed that Europe's fate would be arbitrated by Hitler and Stalin. There began a German-Soviet scramble for the Balkans. Stalin seized Bessarabia, which was assigned to him by Hitler and annexed the strategically placed Northern Bukovina, which was not. While Hitler attacked the Low Lands and France, Stalin first went for Finland and then, simultaneously with Hitler's campaign in the west, annexed the Baltic States. France and Great Britain planned intervention against the Soviets but nothing came of it. Scores were settled with Romania, and Europe seemed to be ready for a new peace conference orchestrated by Hitler, Stalin and Mussolini. The new concert was brought to naught when Molotov's talks in Berlin failed in November 1940 over Bulgaria. Germany emerged as the dominant power, attracting the still independent states of the Balkans and middle Europe like a magnet. Stalin hoped to join the Tripartite Pact, but by then Hitler decided to crush his main ideological opponent.

Even as the Wehrmacht was closing in on Moscow, Stalin told Anthony Eden that the USSR would extend its sphere of influence into Eastern Europe. Stalin would get from the British what Hitler did not deliver: control of the Balkans. Hitler's satellites, Romania, Hungary and Bulgaria hoped that they would be saved 
by a British-American occupation. Instead, in November 1943 the Allies decided to provoke their German occupation without regards to the consequences. The motive was to spread the Germans thin in Normandy and the eastern theater of war. As Allen Dulles put it: "we are up to our elbow in blood, a few hundred thousand lives will not matter." Previously satellite attempts to defect from the Axis had been brushed aside. After the decision was made to open the second front in Normandy, satellite defection was encouraged to force Hitler to invade them, thereby tying down German troops. As the State Department cynically put it: "Adolf [Hitler] aware of decision and informing his boys", German domination would be followed by another occupation, this time Soviet.

Only five years after the north-eastern tier was partitioned between Germany and Russia, in October 1944 Churchill and Stalin divided the Balkans. Churchill later claimed that the percentage agreement was meant to be a temporary arrangement. In reality the Foreign Office had been thinking along these lines since 1942. Romania, the Foreign Office confided to the State Department in early 1943, would be given "to the wolves" and Soviet influence would prevail in the other adjacent countries as well. A formal offer of Romania for Greece had been made to Stalin in early 1944. Roosevelt, who planned a British-Soviet condominium in Europe, applauded the "meeting of minds" between the British and Soviets. American inaction behind the iron curtain until 1948 was not caused by the lack of leverage on the Soviets alone. Rather, Soviet hegemony in Eastern Europe was not so bad for the Americans, who would not take part in the stabilization of Central Europe. The joint chiefs ruled out American participation in military operations in the Balkans citing Soviet superiority; Roosevelt and his military advisors opposed even a subsidiary operation advocated by Churchill. Roosevelt was known for his disinterest in Eastern Europe and under his first presidency Truman did not evidence much either. The Soviet Union's borders as established by the Hitler-Stalin Pact were left standing and the Churchill-Stalin arrangement for Hungary, Romania, Bulgaria and Greece were not seriously challenged either. The U.S. and Britain were virtually shut out of the Soviet-occupied areas; Voroshilov expressed the Soviet mentality succinctly: "this is our territory and we will say who can enter". Hungarian party leader Rákosi proclaimed May 1946: as soon as the peace treaties are signed the "proletariat will be liberated".

Paris saw no security challenge in the westward expansion of the Soviet Union, and neither did the U.S. until 1948. Then an abrupt shift occurred in Washington's position towards Eastern Europe. Rather than regarding Soviet hegemony in Eastern Europe as a stabilizing or at least acceptable condition, the second Truman administration hoped to roll back Soviet power and restore national independence. The Soviet military occupation of Central Europe was now considered as a threat since Eastern Europe "extended Soviet power into the heart of Europe". The United States came to see national independence in Eastern Europe and European 
security as mutually reinforcing conditions. Vigorous policies were implemented to realize the ambitious goal until by 1953 , Soviet nuclear capabilities made subversion and covert operations too dangerous to pursue. The Eisenhower-Dulles platform announced roll back and liberation arguing that the Soviet domination of Eastern Europe was immoral and a threat to U.S. security. Scholarship has emphasized Soviet nuclear deterrence in explaining why the Republican administration backed down from its commitment to liberate Eastern Europe. Yet this explanation fails to explain why Eisenhower did not explore the possibilities of putting any pressure on Khrushchev in 1956 when the Hungarian war of liberation (and the simultaneous turmoil in Poland) brought Moscow in a critical situation. Ultimately the Eisenhower administration may not have found Soviet hegemony less desirable than a retraction of Soviet power. This would bring the United States on the same page as its European allies, none of which saw any advantage in pushing the Soviets out of Eastern Europe.

By the time of the Prague Spring in 1968 the U.S. had completely reappraised its East European policy. Soviet presence there no longer seemed as threatening as in the 1950s, democratic change was occurring in at least some of the satellites that made them less likely to act as proxies of the Soviet Union. Government documents reflect a slow and gradual change in the American position on the future status of Eastern Europe. Continental reunification was no longer on the agenda and neither was the full restoration of independence. Satellites were not to be encouraged to break with the USSR. America would aim at the "development of Western unity in close association with the U.S. a further loosening (but not severing) of abnormally tight bonds between the USSR and Eastern Europe, reduction in divisions between East and West". In fact the removal of Soviet control could lead to a more dangerous world. "Unbridled nationalism in Eastern Europe might lead to possible renewal of the patterns of conflict that made the area such a cockpit prior to pax communista. This potential is evident in complex of latent and potentially dangerous territorial and minority issues in the area."

In 1971 a U.S. diplomat told his audience that the only hope Hungary had for liberation is if change occurs within the Soviet Union itself. A few years later NSC aide Helmut Sonnenfeldt recommended organic relations within the Soviet bloc. There emerged a reform bloc within the Soviet sphere, a situation far from perfect but "not so bad" for the United States. President Carter even noted in his diary that there was no Soviet influence in Hungary.

When the communist regimes in Eastern Europe, first in Poland then in Hungary began to disintegrate the Western powers welcomed and supported change up to the point they threatened to upset the status quo in Europe. The accelerated pace of transformation in 1989 filled capitals from Vienna to Washington with apprehension. 
By 1989 Soviet hegemony in Eastern Europe was seen as a stabilizing factor, the Warsaw Pact a pillar of European stability. Yet, the communist regimes in Eastern Europe were in a state of economic and political decline; without reforms their collapse seemed unavoidable with a potential to destabilize the region. Thus reforms had to be far reaching enough to keep the East European systems afloat, yet stop short of regime change. The reason for caution was not mainly the fear of provoking Soviet intervention, although this may also have been a factor. The West did not just fail to encourage the movement toward regime change, but actually tried to impede regime change and Soviet withdrawal. The EEC declared that it would not allow Comecon states to enter in the foreseeable future many of the products of which were excluded from the common market. A high official of the EEC even asserted that it was Hungary's "duty" to stay in the Warsaw Pact. The French socialists admonished the Hungarian party not to lose ground to the opposition. German chancellor Kohl warned the HSWP not to lose control of the levers of power; Thatcher pleaded with Gorbachev to stay in Eastern Europe; Bush wanted Jaruzelski to stay and supported communist reformers in Budapest against the opposition declaring that US-Hungarian relations should not impair Hungary's relationship with the USSR, he "did not want to cause problems for Hungary or Gorbachev". Mitterrand's vision, as he explained in Budapest in January 1990 was a divided continent on a cooperative basis. Once more, national self-determination was seen as contradictory to the principle of stability. Austria, Switzerland and Italy were also much concerned. Austria was worried about refugees and a potential spillover of crises. For Italy and France the prospect of German domination in Mitteleuropa was not more appealing than continued Soviet control - the extent of which was never entirely clear in the Western world.

The main fear was for Gorbachev and his political future which would be in jeopardy if the Soviets lost Eastern Europe. Gorbachev was not planning on losing the empire and hoped to contain changes within the confines of "socialism" and the existing international structure in Europe. He was the first unambiguously pro-Western Soviet leader, who signed important arms reduction agreements, therefore his political survival enjoyed priority self-determination. Thus when in Budapest Bush signaled that although not disinterested in the events, the United States respected the Soviet Union's sphere of influence.

In addition, as Lawrence Eagleburger pointed out, a liberated Eastern Europe may not be a more stable place. Old national rivalries and hostilities may come to the surface, bringing instability to the region and potentially the continent. Last but not least, there were French worries that the developments in Eastern Europe could delay the Maastricht process.

All these concerns led NATO powers to seek the preservation of the international system that was based on a divided Europe, albeit on a more cooperative, 
non-competitive basis. The initiative to break with Yalta came from Eastern Europe, which for the first time since 1918, was able to control its destiny.

The destruction of Austria-Hungary created a highly unstable and vulnerable space in the middle of Europe. Munich in 1938, the Western non-response to the Hitler-Stalin pact, the percentage agreement, Truman's inaction in the years of Soviet penetration in Eastern Europe were not mistakes in policies dealing with dictatorial, expansionist powers and the search for a new and lasting European balance. The history of international relations in the areas between Germany and Russia needs reinterpretation. The stability/national self-determination paradigm offers an analytical framework in which it is possible to analyze the policies of Western powers towards the region between 1918 and 1990. The national independence of the weak states in the area is guaranteed by Western powers in case this condition is seen to be consistent with the principle of stability and security. If history is a good guide to the future membership in the European Union may guarantee that the two conditions will be mutually reinforcing. 